\title{
The Perfect Tawhid Model Proportional to Tok Ku Paloh, Nineteenth-Century Malaysian Sufis
}

\author{
Omar S. H. S., Zin E. I. E. W., Yahya, N. H.
}

To Link this Article: http://dx.doi.org/10.6007/IJARBSS/v11-i12/11850

DOI:10.6007/IJARBSS/v11-i12/11850

Received: 02 October 2021, Revised: 07 November 2021, Accepted: 27 November 2021

Published Online: 15 December 2021

In-Text Citation: (Omar et al., 2021)

To Cite this Article: Omar, S. H. S., Zin, E. I. E. W., \& Yahya, N. H. (2021). The Perfect Tawhid Model Proportional to Tok Ku Paloh, Nineteenth-Century Malaysian Sufis. International Journal of Academic Research in Business and Social Sciences, 11(12), 1010-1015.

\section{Copyright: (c) 2021 The Author(s)}

Published by Human Resource Management Academic Research Society (www.hrmars.com) This article is published under the Creative Commons Attribution (CC BY 4.0) license. Anyone may reproduce, distribute, translate and create derivative works of this article (for both commercial and non0-commercial purposes), subject to full attribution to the original publication and authors. The full terms of this license may be seen at: http://creativecommons.org/licences/by/4.0/legalcode

Vol. 11, No. 12, 2021, Pg. $1010-1015$

Full Terms \& Conditions of access and use can be found at http://hrmars.com/index.php/pages/detail/publication-ethics 


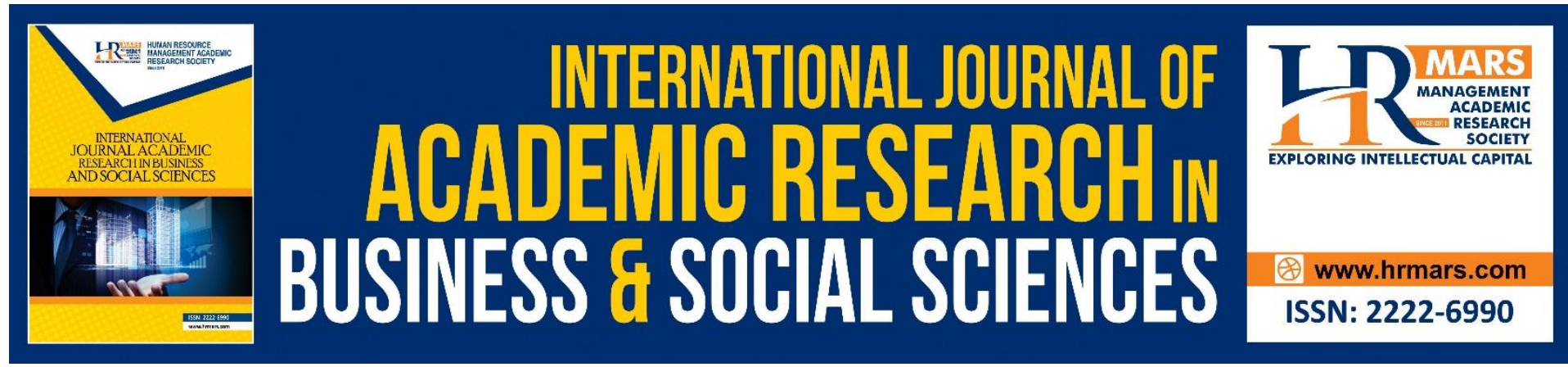

\title{
The Perfect Tawhid Model Proportional to Tok Ku Paloh, Nineteenth-Century Malaysian Sufis
}

\author{
Omar S. H. S., Zin E. I. E. W., Yahya, N. H. \\ Faculty of Contemporary Islamic Study, Research Institute for Islamic Products \& Civilization \\ (INSPIRE), Universiti Sultan Zainal Abidin, Gong Badak Campus, 21300 Kuala Terengganu, \\ Terengganu, Malaysia. \\ Email: sylutfi@unisza.edu.my
}

\begin{abstract}
The appreciation of monotheism in Islam (Tawhid) is one of the essential aspects that are frequently addressed, precisely in the Islamic faith by the ulama Aqidah and the Sufi scholars in the discipline of discipline Sufism. However, there are still not many studies emphasizing that it is associated explicitly with Malaysian scholarly. This study aims to shine a light on the implementation model of Tawhid Haqiqi (Perfect Tawhid) in line with the renowned Sufi figure in the archipelago, namely Sayyid Abdul Rahman Bin Muhammad Bin Zayn al-Idrus, also known as Tok Ku Paloh. This qualitative study uses a content analysis approach based on the scholar's work to obtain his particular thought written into his principal manuscript titled Ma'arij al-Lahfan Li al-Taraqqi Ila Haqaiq al-Irfan. The study came up with a model named Tauhid Haqiqi Tok Ku Model, referring to the implementation of an authentic monotheism according to his well-grounded theory on the sentence of Tawhid La Ilahi Illa Allah. The study found that applying values to the soul appreciates that only Allah has actual existence. Thus, all beings must only wish to Allah to create each moment of his existence, for they do not have the fact of real presence. The realization of values is so-called authentic monotheism. The research concludes that Tawhid Haqiqi's model can develop the personality of a Muhsin proposed by the Prophet. only Allah as if you see Him. Otherwise, you feel as if He is watching over you at all times.
\end{abstract}

Keywords: Tawhid Haqiqi's Model, Sayyid Abdul Rahman, Tok Ku Paloh, Ma`arij al-Lahfan.

\section{Introduction}

The appreciation of monotheism in Islam (Tawhid) is an essential aspect that is often explicitly discussed in the Islamic Faith by the ulama Aqidah and the Sufis scholars in the discipline of Sufism. However, there are still not many studies highlighting it related explicitly to Malay scholars. This study aims to highlight the model of the implementation of Tawhid Haqiqi (perfect monotheism) in line with the famous Sufi figure in the archipelago's 19th-century Sufi figure ulama in Terengganu.

The brief biography of the scholar, as mentioned earlier, is Sayyid Abdul Rahman bin Sayyid Muhammad bin Zayn al-Abidin al-Aydarus. However, he is widely known as Tok Ku Paloh. 
Other appointees include Engku Sayyid Paloh, Engku Cik, Tuan Cik, and Syeikh al-Islam Terengganu (Zaki, 2007). He was born in 1236 AH, coincides with 1820 AD in Chabang Tiga Village, Kuala Terengganu, and reported his death on the 1st Zulhijjah $1337 \mathrm{AH}$ equal to 6 September 1918 AD (Mohammad, 1983), roughly his age of 100 years (Omar et al., 2017).

During his lifetime between 1820 and 1918, he was fortunate to serve under the orders of some sultans of Terengganu. For instance; Sultan Abdul Rahman (1830 AD), Sultan Daud (1830-1831 AD), Sultan Mansur II (1831-1837 AD), Sultan Muhammad (1837-1839 AD), Baginda Omar (1839-1876 AD), Sultan Ahmad Shah II (1876-1881 AD) and the last was Sultan Zainal Abidin III (1881-1918 AD), the prince of Sultan Ahmad Shah II (www.istana.terengganu.gov).

Nevertheless, the significant attachment between Tok Ku Paloh and the institution of the Terengganu Sultanate was highlighted during the reign of Sultan Zainal Abidin III (Muhammad, 1991: 183). The researchers reported he actively contributed good ideas whenever the Sultan was involved in the tethered situation. Henceforth, he received the trust from Sultan Zainal Abidin III as his advisor (Muhammad, 1991).

He was also appointed to be as "Shaykhul Ulama"' or the chief leader of the ulama by Sultan Zainal Abidin III after the demise of his father, which was known as Tok Ku Tuan Besar. Besides, Tok Ku Paloh also held a position in the Terengganu state political affairs during his time. He was assigned as one of the committees in the Legislative Councils and the Raja Anak Sungai (King of the Stream) during the reign of Sultan Zainal Abidin III. Besides, he performed his responsibility by assisting the Sultan in the administration and managing the rulership of Terengganu (Muhammad, 1991).

The excellent relationship between Tok Ku Paloh and Sultan Zainal Abidin III as recorded in the historical accounts indicates the harmonious attachment between the ruler and ulama'. This situation suggests that a ruler also put a closer affiliation with an ulama' for the sake of religious knowledge. Hence, the contiguous relationship between Sultan and Tok Ku Paloh has shifted the Sultan to be pious and strictly adhered to the Islamic teachings during his leadership era (Muhammad, 1991).

\section{Research Methodology}

This qualitative study uses a content analysis approach based on the scholar's work to obtain his particular thought written into his principal manuscript titled Ma'arij al-Lahfan Li alTaraqqi Ila Haqaiq al-Irfan (The Ladder for the Thirsty to Achieve. Ma'rifa) (Hadzrullathfi et al., 2012). This Kitab of Ma'arij al-Lahfan is a book that contains the gists of knowledge related to Tawhid, Tasawwuf, and Tariqa (Zaki, 2007). The study comes out with the Tawhid Haqiqi's model based on the thought of Tok Ku Paloh highlighted in the first chapter, which is Tawhid, chapter two of ma'rifah (gnosis), and the third chapter of the Sufis path.

\section{The Findings Discussion}

Tok Ku Paloh highlights one of the essential characteristics in the construction of genuine mukmin, which is the appreciation of his slavery to his God to produce a true Tawhid that eventually can eliminate all forms of shirk, either exoterically or esoterically. He strictly asserts: 
But no the perfection of the level of slavery (tahqiq martabah 'ubudiyyah) until the perfect tawhid is worn, cum disavowed both exoteric (jali) and esoteric (khafi) shirk (Rahman, 1300AH).

As stated above, to reach perfect tawhid, one has to follow four educational paths, as indicated in his statement:

Hence, it is compulsory to utter all the hidden gems of knowledge from the perfect tawhid and ma'rifah and through four ways of tawhid, ma'rifah, tariqah and haqiqah... (Rahman, $1300 \mathrm{AH}$ ).

According to the thought of Tok Ku Paloh, the starting point for understanding the perfect tawhid is actually with the essence and meaning of the two sentences of shahadah (testimony), that is, the La llaha Illa Allah as clearly presented in his writings:

The term Tawhid contains two fundamental meanings, namely denial, and conviction. The disclaimer is that everything believed to exist in illusions is the same as the existence of God. While the belief is that only the perfect God's existence and His divinity. (Rahman, $1300 \mathrm{AH}$ ).

Based on the above statements, Tok Ku Paloh proposed a form of unique practice that leads to his understanding that the perfect tawhid is the act of remembering Allah. However, through the perspective of Tok Ku Paloh, the concept of God's remembrance is not simply by invoking the names of Allah verbally or heart. He stressed that the memorial of Allah must be engaged in his heart with a firm belief in the perfection and majesty of Allah. And this is the primary purpose for reaching the perfect tawhid and makrifah Allah.

\section{The Development of Perfect Tawhid Model}

From Tok Ku Paloh's treatise, he started his discussion with the importance of completing the essence of tawhid to Allah. However, the tawhid referred to by Tok Ku Paloh is not enough with the intellect's conviction about asserting tawhid and the sovereignty of Allah, but it requires the tawhid that one had on the way to dhawqi (tasting, the first direct experience) (Rahman, $1300 \mathrm{AH}$ ).

The author believes that the term dhawqi is a result or effect of the firmness of the heart's trust in the perfection and majesty of Allah, which is fascinated by the practice of remembering Allah continually. In another word, tawhid in a context of dhawqi is produced whenever the firm certainty towards the perfection and the sovereignty of Allah. The continuous and constant relationship with Allah by the practices of remembering Allah has undoubtedly generated the strength of tawhid.

As according to Tok Ku Paloh, ma'rifah Allah is referring to the achievement of a mu'min (faithful individual) in knowing Allah at a perfect level or can be defined as the stage of ihsan. Knowing Allah is also a gist towards the meaning of "ubudiyyah: the main purpose of the creation of jinni and man as how understood by Ibn 'Abbas r.a. (Ibn-Kathir, 1990). Hence, taken as a whole picture, the referred concept of ma'rifah Allah is apparently closely related to the concept of tawhid haqiqi as how presented by Tok Ku Paloh. For that, the authors can 
assume that the ma'rifah Allah as how promulgated by this scholar is the peak of manifestation in understanding tawhid from the way of dhawqi.

Briefly, at the moment of remembering Allah, that particular feature will help an individual to form a firm certainty on Him, hence the harmonious tawhid is formed and eventually establish the perfect ma'rifah Allah. If the depth study conducted on the understanding towards the concept of the remembrance of Allah that is presented by Tok Ku Paloh, it is synonymous with the concept and the recommendation to remember Allah as how stated in the al-Quran and Sunnah Rasulullah pbuh.

\section{Remembering Allah is The Path of Perfect Tawhid's Implementation}

From the above discussion, it is understandable that the tawhid haqiqi is closely attached to the ma'rifah Allah. Meanwhile, the latter is attainable through the practices of remembering Allah. Hence this kind of ritual is regarded as the vital foundation within the thought of Tok $\mathrm{Ku}$ Paloh. According to him, it is necessary to go through three levels of remembrance of Allah to qualify to possess tawhid haqiqi. (Norhashimah, 2014).

First, the individual who verbally invokes La llaha Illa Allah, while the heart is thoughtless and does not even realize the meaning of tawhid contained in that invoked holy sentence, is not qualified to possess the tawhid haqiqi. In practice, he is probably a munafiq, although, under Islamic law, he is a Muslim.

The second, the individual who verbally utters the name of Allah and at the same time remembers Him in heart. Or at least, one realizes the meaning of tawhid contained in that invoked dhikr. The second, the individual who verbally utters the name of Allah and at the same time remembers Him in the heart. Alternatively, at least, one realizes the meaning of tawhid contained in that invoked dhikr. While the sense of tawhid exists globally within the soul, one has risen to mu'min level. Henceforth, the fluctuated state of iman depends on the depth of the ability to understand that particular essence of tawhid.

The difference between these two categories is the aspect of inadvertency and the heart's consciousness. Whenever an individual's level of negligence and the abstracted mind increase, they will fall into the first category. In other words, the firmness of remembering Allah in this second stage is not stable.

In the third category, Tok Ku Paloh illustrates the individual's position that is constantly remembering Allah as one whose heart is captivated and vigorously meditating on the greatness and sovereignty of Allah. According to Tok Ku Paloh, this particular individual is not solely remembering Allah by the heart, but the soul (ruh) is also remembering and witnessing the perfectness of Allah (Adam et al., 2020). Hence, anyone that falls into this category has reached according to the essence of tawhid haqiqi.

\section{Conclusion}

According to Tok Ku Paloh, the development of perfect Tawhid is initially coming from the understanding of La llaha Illa Allah. The essence of this phrase is annihilating all forms of existences that do not have the authentic existence as Allah exists. Only attaching the existence of Allah is pure and characterized will all the godly attributes. Reaching this 
particular perfect Tawhid is through three processes of remembering Allah, which ultimately establish an individual to be stated as the personality of a Muhsin proposed by the Prophet :that you become the servant of God who adores only Allah as if you see Him. Otherwise, you feel as if $\mathrm{He}$ is watching over you at all times.

\section{Acknowledgement}

This article is part of a research fund sponsored by the Center for Research and Innovation (RMIC), Sultan Zainal Abidin University (UniSZA), Gong Badak Campus 21300 Kuala Nerus, Terengganu, Malaysia.

\section{Reference}

Adam, N. S., Omar, S. H. S., Baru, R., Ali, M. S., Ismail, M. S., Zin, E. I. E. W., \& Mat@Mohamad, M. Z. (2020). Fana 'As Stress Therapy According To Al-Ghazali Through Kitab Al-Arba'in Fi Usul Al-Din. International Journal of Academic Research in Business and Social Science, 10(11), 1282-1288.

Adam, N. S., Omar, S. H. S., Baru, R., Ali, M. S., Ismail, M. S., Zin, E. I. E. W., \& Mat@Mohamad, M. Z. (2020). Therapy of Zuhd Based on Al- Ghazali Spiritual Theory Through Kitab AlArbain Fi Usul Al-Din. International Journal of Academic Research in Business and Social Sciences. 10(11), 1298-1304.

Alwi, E. A. Z. E. (2007). Tokoh Ulama Negeri Terengganu: Biografi, Pemikiran \& Sumbangan. Terengganu: Majlis Agama Islam Dan Adat Istiadat Melayu (MAIDAM).

Ibn-Kathir. (1990). Tafsir al-Quran al-Azim Ibnu Kathir. Vol.4. Kaherah: Dar al-Hadith.

Bakar, M. A. (1991). Ulama Terengganu Suatu Sorotan: Ulama' dan Umara': Tok Ku Paloh dan Pemerintahan Islam. Kuala Lumpur: Utusan Publication Dan Distributors.

Yahya, N. (2014). "Konsep Dan Kayfiyyat Tahlil Menurut Tok Ku Paloh Dalam Kitab Macarij AlLahfan Li Al-Taraqqi Ila Haqaiq Al-'Irfan”. Unpublished master's thesis. Terengganu: Universiti Sultan Zainal Abidin.

Omar, S. H. S., Fadzli, A., Baru, R., \& Norhashimah, Y. (2017). Tok Ku Paloh's Manual on Suf Practices in Ma'arij Al-Lahfan Li Al-Taraqqi Ila Haqaiq Al-'irfan. Pertanika J. Soc. Sci. \& Hum. 25 (S): 1 - 12

Omar, S. H. S., Zin, E. I. E. W., Baru, R., \& Chik, W. M. Y. W. (2012). Pendokumentasian Karya Ulama Terengganu Abad Ke 19 Dalam Memartabatkan Pengajian Ilmu-Ilmu Berteraskan al-Quran Di Terengganu. University's Research. Terengganu: Universiti Sultan Zainal Abidin.

Rahman, S. A. (1300H). Kitab Macarij Al-Lahfan Li Al-Taraqqi Ila Haqaiq Al-'Irfan. N.d. 